\title{
Airway responsiveness of firefighters after smoke
} exposure

\author{
K S Chia, J Jeyaratnam, T B Chan, T K Lim
}

\begin{abstract}
Ventilatory function and airway reactivity of 20 firefighters were studied one hour before and one hour after exposure in a smoke chamber. None showed an increase in airway reactivity to inhaled histamine before exposure. Eight $(80 \%)$ of the regular firefighters, however, had an increase in airway reactivity after exposure in the smoke chamber. After six hours, three of the firefighters still had increased airway reactivity. All were nonreactive after 24 hours but the ventilatory function of the three firefighters who were reactive after six hours did not return to baseline values. The duration of service as a firefighter is the major contributing factor to the change in airway reactivity. This increase in airway responsiveness among regular firefighters suggests that some form of chronic epithelial injury is needed before an increase in airway responsiveness is seen.
\end{abstract}

Firefighters are exposed to a wide variety of respiratory hazards including ozone, sulphur dioxide, carbon monoxide, oxides of nitrogen, aldehydes, hydrogen chloride, and particulates. ${ }^{1-4}$ Acute reduction in pulmonary function after exposure to the products of combustion is well documented..$^{5-7}$ The changes in airway responsiveness are, however, not. ${ }^{8}$ Determining the changes in airway responsiveness can help in understanding the mechanisms of airway obstruction and may identify persons with high risk of chronic obstructive pulmonary disease. This paper describes the changes in airway responsiveness in a group if firefighters after exposure in a smoke chamber and analyses the factors contributing to this change.

Division of Occupational Medicine, Department of Community, Occupational, and Family Medicine, National University of Singapore, Singapore 0511, Republic of Singapore

K S Chia, J Jeyaratnam

Division of Respiratory Medicine, Department of Medicine, National University of Singapore

T B Chan, T K Lim

\section{Methods}

STUDY POPULATION

Two groups of male Malay firefighters volunteered $\stackrel{+}{-}$ for exposure in a smoke chamber without protective $\infty$ respiratory equipment. The first group consisted of $N$ 10 recruits who had not been firefighting but had + been inside the smoke chamber on two previous 5 occasions. The second group were regular firefighters. From a questionnaire none of the subjects had a history of chronic cough, chronic phlegm production, wheezing, asthma, or atopy.

\section{SPIROMETRY AND HISTAMINE CHALLENGE}

Baseline spirometry and a histamine challenge test (HCT) were performed one hour before exposure in the smoke chamber. At the time of baseline spirometry and HCT no subject had fought a fire for $\mathbb{D}$ the previous 72 hours nor had had any respiratory $\stackrel{\varrho}{\Rightarrow}$ tract infections during the previous two weeks. All the volunteers were required to refrain from smoking and drinking caffeinated beverages for eight hours before the tests. Spirometry was performed using a Fleisch type pneumotach spirometer. A minimum of $\stackrel{\odot}{\triangle}$ three acceptable tracings were obtained with the $?$ subjects in a standing position without nose clips. $\frac{5}{3}$ The tracing with the largest forced vital capacity (FVC) and forced expiratory volume in one second $O$ $\left(\mathrm{FEV}_{1}\right)$ was used for analysis. The FEV, FVC, and forced expiratory flow rates $\left(\mathrm{FEF}_{25-75^{\circ}}, \mathrm{FEF}_{75-85^{\circ}}\right.$, 은 $\mathrm{FEF}_{50^{\circ},}$, and $\mathrm{FEF}_{75^{\circ}}$ ) were obtained using standard $\frac{\mathrm{D}}{\mathrm{O}}$ techniques. $^{910}$

The HCT was performed using standard concen- $N$ trations of histamine diphosphate solution delivered by a hand held De Vibliss No 40 glass nebuliser. The $\mathcal{O}$ mouthpiece of the nebuliser was placed between the $\tilde{\omega}$ teeth of the subject who exhaled to slightly below? functional residual capacity (FRC) and then inhaledo slowly over one to two seconds towards total lung $\overparen{\mathscr{\Phi}}$ capacity (TLC), at which stage he was required to $\stackrel{?}{+}$ hold his breath for three seconds. At the beginning of $T$ inspiration the operator gave the bulb of the nebuliser one firm squeeze. The $\mathrm{FEV}_{1}$ was measured $60 \stackrel{\overbrace{}}{\overparen{\Omega}}$ seconds after each dose and followed immediately by $\stackrel{\mathbb{Q}}{\Omega}$ the next dose. The challenge was stopped when the $\mathrm{FEV}_{1}$ fell by more than $20 \%$ from the postsaline value or when the maximum dose of $3.9 \mu \mathrm{mol}$ was응 
delivered. The provocative dose of histamine causing a $20 \%$ fall in $\mathrm{FEV}_{1}\left(\mathrm{PD}_{20}\right)$ was determined by plotting the percentage change in $\mathrm{FEV}_{1}$ from the postsaline value on a linear scale against the log dose of histamine. ${ }^{11}$ If subjects did not respond by the end of the protocol, the largest dose of $3.9 \mu \mathrm{mol}$ was assigned to the $\mathrm{PD}_{20}$ for analysis.

The smoke chamber is a large enclosed building with a simple obstacle course within. The firefighters were to negotiate the obstacles using their helmet lights for illumination. Smoke was produced by controlled combustion of a mixture of diesel oil, petrol, wood dust, and plastics.

Spirometry and HCT were repeated one hour after exposure in the smoke chamber. Those subjects with increased airway responsiveness had the HCT repeated six and 24 hours after exposure.

\section{STATISTICAL ANALYSIS}

Statistical analysis of changes from baseline spirometry was undertaken using a paired $t$ test. Comparison of the changes in ventilatory function between recruits and regulars were adjusted for age, height, length of service, duration of exposure in the smoke chamber, pack-years of smoking, and the preexposure level using analysis of covariance (J Lee, personal communication). The factors contributing to the change in $\mathrm{PD}_{20}$ were analysed by comparing the standardised partial regression coefficients through multiple linear regression analysis. The postexposure $F E V_{1}$ was entered as one of the independent variables to assess the effect of a change in baseline airway calibre. ${ }^{12}$

\section{Results}

GENERAL CHARACTERISTICS OF STUDY POPULATION

The recruits were slightly younger (age range 17-22) than the regular firefighters (age range 21-29). The regulars had been in firefighting for an average of 4.6 years (range 1-9 years). All 20 firefighters were smokers with the regulars having a slightly higher
Table 1 General description of study population of firefighters

\begin{tabular}{lrr}
\hline & $\begin{array}{l}\text { Recruits } \\
\text { Mean }(S D)\end{array}$ & \multicolumn{1}{c}{$\begin{array}{l}\text { Regulars } \\
\text { Mean }(S D)\end{array}$} \\
\hline Age (y) & $19 \cdot 5(1 \cdot 58)$ & $25 \cdot 1(3 \cdot 21)$ \\
Height (cm) & $170 \cdot 5(4 \cdot 79)$ & $170 \cdot 0(6 \cdot 86)$ \\
Length of service $(y)$ & - & $4 \cdot 6(2 \cdot 55)$ \\
Pack-years of smoking & $2.9(1 \cdot 29)$ & $4 \cdot 2(1.93)$ \\
\hline
\end{tabular}

pack-years of smoking (table 1). The recruits spent 10.8 minutes and the regulars 11.8 minutes in the smoke chamber.

\section{CHANGES IN VENTILATORY FUNCTION}

Small changes in ventilatory function were seen among the recruits after exposure in the smoke chamber $(-1.8 \%$ to $3.0 \%)$. These were not statistically significant. Changes in the regular firefighters were greater in magnitude and were statistically significant. The largest change was in $\mathrm{FEF}_{75^{\circ}}$ (table 2 ). The differences in the changes in ventilatory function between recruits and regulars were not statistically significant (table 3 ).

Ventilatory indices for recruits returned to preexposure levels within six hours. In four of the regular firefighters, ventilatory function did not return to pre-exposure levels even after 24 hours despite administration of a bronchodilator.

\section{CHANGES IN AIRWAY RESPONSIVENESS}

The 20 subjects showed no increased airway responsiveness before exposure in the smoke chamber. None of the recruits was responsive after exposure but eight $(80 \%)$ of the regulars became responsive after exposure. Of these, three continued to be responsive after six hours and all were non-responsive after 24 hours. Ventilatory function of the three regulars who were responsive after six hours, however, did not return to pre-exposure levels despite administration of a bronchodilator.

The duration of service as a firefighter seems to

Table 2 Mean and percentage changes in ventilatory function and airway responsivenesss after exposure in a smoke chamber

\begin{tabular}{|c|c|c|c|c|c|c|}
\hline & \multicolumn{3}{|l|}{ Recruits } & \multicolumn{3}{|c|}{ Regulars } \\
\hline & Before & After & Difference (\%) & Before & After & Difference (\%) \\
\hline $\begin{array}{l}\text { FEV }_{1} \\
\text { FVC } \\
\text { FEF }_{25-75 \%} \\
\text { FEF }_{75-85 \%} \\
\text { FEF }_{50 \%} \\
\text { FEF }_{75 \%} \\
\text { PD }_{20}\end{array}$ & $\begin{array}{l}3 \cdot 54 \\
4 \cdot 01 \\
4 \cdot 25 \\
1 \cdot 80 \\
4 \cdot 56 \\
2 \cdot 20 \\
3 \cdot 91\end{array}$ & $\begin{array}{l}3 \cdot 52 \\
4 \cdot 08 \\
4 \cdot 20 \\
1 \cdot 78 \\
4 \cdot 48 \\
2 \cdot 27 \\
3 \cdot 91\end{array}$ & $\begin{array}{c}-0.02(-0.6) \\
0.07(1.7) \\
-0.05(-1.2) \\
-0.02(-1.1) \\
-0.08(-1.8) \\
0.07(3.2) \\
0.00(0.0)\end{array}$ & $\begin{array}{l}3 \cdot 59 \\
4 \cdot 05 \\
4 \cdot 21 \\
1 \cdot 84 \\
4 \cdot 40 \\
2 \cdot 23 \\
3 \cdot 91\end{array}$ & $\begin{array}{l}3 \cdot 55 \\
4 \cdot 05 \\
4 \cdot 05 \\
1 \cdot 67 \\
4 \cdot 03 \\
2 \cdot 00 \\
2 \cdot 15\end{array}$ & $\begin{array}{l}-0.04(-1.1)^{\star} \\
0.00(0.0) \\
-0.16(-3.8)^{\star} \\
-0.18(-9.8)^{\star} \\
-0.37(-8.4)^{\star} \\
-0.23(-10.3)^{\star} \\
-1.76(-45.0)\end{array}$ \\
\hline
\end{tabular}

${ }^{\star} \mathrm{p}<0.01$ (paired $t$ test).

Difference $=$ after - before.

$\%=$ Difference/before $\times 100$. 
Table 3 Changes in ventilatory function between recruits and regulars adjusted for age, height, duration of service, time in smoke chamber, and pre-exposure indices. *

\begin{tabular}{|c|c|c|c|c|c|}
\hline & \multicolumn{2}{|l|}{ Recruits } & \multicolumn{2}{|l|}{ Regulars } & \multirow[b]{2}{*}{$\stackrel{p}{\text { Value }}$} \\
\hline & $\begin{array}{l}\text { Difference } \\
\text { Un- } \\
\text { adjusted }\end{array}$ & $\begin{array}{l}\text { (after-before) } \\
\text { Adjusted }\end{array}$ & $\begin{array}{l}\text { Un- } \\
\text { adjusted }\end{array}$ & Adjusted & \\
\hline $\begin{array}{l}\text { FEV } \\
\text { FVC }_{1} \\
\text { FEF }_{25-75^{\circ}} \\
\text { FEF }_{75-85^{\circ}} \\
\text { FEF }_{50} \\
\text { FEF }_{75}\end{array}$ & $\begin{array}{r}-0.02 \\
0.07 \\
-0.05 \\
-0.02 \\
-0.08 \\
0.07\end{array}$ & $\begin{array}{r}0.01 \\
0.07 \\
-0.05 \\
0.01 \\
-0.07 \\
0.03\end{array}$ & $\begin{array}{r}-0.04 \\
0.00 \\
-0.16 \\
-0.18 \\
-0.37 \\
-0.23\end{array}$ & $\begin{array}{r}0.07 \\
0.00 \\
-0.16 \\
-0.20 \\
-0.39 \\
-0.20\end{array}$ & $\begin{array}{l}0 \cdot 23 \\
0 \cdot 34 \\
0 \cdot 66 \\
0 \cdot 31 \\
0 \cdot 11 \\
0 \cdot 19\end{array}$ \\
\hline
\end{tabular}

^By analysis of covariance (ANCOVA).

provide the greatest contribution to the change in $\mathrm{PD}_{20}$ (table 4). The postexposure $\mathrm{FEV}_{1}$ is not a major contributory factor when compared with the duration of service.

\section{Discussion}

Firefighters can be expected to show an increase in airway responsiveness after exposure to products of pyrolysis. Products such as ozone, ${ }^{1314}$ sulphur dioxide, ${ }^{15}$ and oxides of nitrogen ${ }^{16}$ have been shown to increase airway responsiveness in some subjects. Changes in airway responsiveness after fire exposure, however, have not been adequately described. ${ }^{8}$ This study showed that changes in airway responsiveness are confined to those subjects with a fairly long history of firefighting activities.

The exact mechanism of increased airway responsiveness is uncertain. No single mechanism could explain the increase in airway responsiveness following exposure to products of combustion. Ozone, ${ }^{13} 14$ sulphur dioxide, ${ }^{15}$ and cigarette smoke ${ }^{17}$ are known to cause increases in airway reactivity through reflex bronchoconstriction and could explain the findings for the regular firefighters. For at least four of the

Table 4 Factors influencing change in airway responsiveness among regular firefighters $(n=10)$

\begin{tabular}{|c|c|c|c|c|}
\hline $\begin{array}{l}\text { Independent } \\
\text { variables }\end{array}$ & $\begin{array}{l}\text { Partial } \\
\text { regression } \\
\text { coefficients }\end{array}$ & $\begin{array}{l}\text { Standardised } \\
\text { partial } \\
\text { regression } \\
\text { coefficients }\end{array}$ & p Value & $R^{2}$ \\
\hline $\begin{array}{l}\text { Age (y) } \\
\text { Height (cm) } \\
\text { Duration* } \\
\text { Pack-years } \\
\text { Exposure } † \\
\text { Post FEV } \ddagger\end{array}$ & $\begin{array}{r}0.049 \\
0.052 \\
-0.436 \\
-0.123 \\
-0.194 \\
-1.323\end{array}$ & $\begin{array}{r}0.119 \\
0.275 \\
-0.843 \\
-0.180 \\
-0.258 \\
-0.221\end{array}$ & $\begin{array}{l}0.11 \\
0.28 \\
0.84 \\
0.18 \\
0.26 \\
0.46\end{array}$ & 0.73 \\
\hline
\end{tabular}

*Duration of service as a firefighter $(y)$.

tExposure time in smoke chamber (minutes).

†Postexposure $\mathrm{FEV}_{1}(\mathrm{l} / \mathrm{s})$ regular firefighters, however, the reduction in ven tilatory indices could not be fully explained by refles bronchoconstriction, as they failed to return to pree exposure levels after 24 hours and administration of bronchodilator. This may be because of ongoin inflammatory response in the airways. There is als\$ evidence that in airway inflammation the vagal reflexu is more sensitive or more active. Inhalation of $0.6 \mathrm{ppm}$ ozone for two hours caused an increased response to histamine and metacholine. This enhan $\overrightarrow{-}$ ced responsiveness to histamine was diminishe greatly by large doses of atropine, which suggest? that postganglionic vagal endings become more active after bronchial irritation of inflammation caused by ozone. ${ }^{13}{ }^{14}$ Furthermore, airway inflammaeo tion causes bronchoconstriction and this may cause increased proximal bronchial deposition of inhaled substances, thus contributing to an increase in cen 을 tral airway resistance. This has been shown to shift the dose response curve for histamine to the left. ${ }^{19}$

The greater magnitude of change in ventilator function and increase in airway responsiveness ${ }^{+}$ among the regular firefighters compared witho recruits suggests that some form of chronic epitheliạ injury is needed before an increase in airway respone siveness is seen. Such injury may increase the sensitivity of airway receptors or increase the per meability of the respiratory epithelium.

The lack of power in this study may have preब cluded the finding of statistically significant factors contributing to the change in $\mathrm{PD}_{20}$. The magnitude of the standardised partial regression coefficients, however, clearly showed the duration of service as firefighter to be the major factor contributing to the increase in airway reactivity after exposure. The change in baseline $F E V_{1}$ could be a confounding factor ${ }^{12}$ but its contribution is small in relation to the duration of service.

The degree of physical exercise in negotiating thê obstacle course inside the smoke chamber may contribute to an increase in airway responsiveness음 Furthermore, a less fit firefighter may spend more time in the smoke chamber as well as having a higher. rate of respiration. The effect of physical exercisen however, was reduced by performing the HCT one hour after exposure in the smoke chamber and the effect of variable dose of exposure was partiallyw adjusted for by using the time spent in the smoke chamber in the analysis.

This study does not allow any further conclusions to be drawn as to whether repeated exposures to fire? will cause persistent airway hyperresponsiveness oro rapid deterioration in lung function. Airway respon? siveness, however, has been postulated to be a risk factor for the subsequent development of chroni@ obstructive pulmonary disease. ${ }^{19}$ The increase in airway responsiveness among regular firefighters suggests therefore, that these firefighters are at ap 
increased risk of accelerated loss in pulmonary function.

We thank the Singapore Fire Service for their participation. The study was supported by a grant from the National University of Singapore (RP870361).

1 Brandt-Rauf PW, Fallon Jr LF, Tarantini T, Idema C, Andrew L. Health hazards of fire fighters: exposure assessment. $B r J$ Ind Med 1988;45:606-12.

2 Terrill JB, Montgomery RR, Reinhardt CF. Toxic gases from fires. Science 1978;200:1343-7.

3 Hartzell GE, Packham SC, Switzer WG. Toxic products from fires. Am Ind Hyg Assoc J 1983;44:248-55.

4 Treitman RD, Burgess WA, Gold A. Air contaminants encountered by fire-fighters. Am Ind Hyg Assoc J 1980;41:796-802.

5 Sheppard D, Distefano S, Morse L, Becker C. Acute effects of routine firefighting on pulmonary function. $\mathrm{Am} J$ Ind $\mathrm{Med}$ 1986;9:333-40.

6 Musk AW, Smith JM, McLaughlin E. Pulmonary function in fire fighters: acute changes in ventilatory capacity and their correlates. Br J Ind Med 1979;36:29-34.

7 Loke J, Farmer W, Matthay RA, Putman CE, Smith GJ. Acute and chronic effects of fire fighting on pulmonary function. Chest 1980;77:369-73.

8 Sherman CB, Barnhart S, Miller MF, et al. Firefighting acutely increases airway responsiveness. Am Rev Respir Dis 1989;140:185-90.

9 Gardner RM, Hankinson JL, Clausen JL, Crapo RO, Johnson
RL, Epler GR. Standardisation of spirometry-1987 update. Am Rev Respir Dis 1987;136:1285-98.

10 Ferris BG. Epidemiologic standardisation project. Am Rev Respir Dis 1978;118:7-53.

11 Yan K, Salome C, Woolcock AJ. Rapid method for measurement of bronchial responsiveness. Thorax 1983;38:760-5.

12 Pare PD, Wiggs BJ. Baseline airway caliber: a confounder in interpreting bronchoconstriction and bronchodilatation. Chest 1989;96:964-5.

13 Golden JA, Nadel JA, Boushey HA. Bronchial hyperirritability in healthy subjects after exposure to ozone. Am Rev Respir Dis 1978;118:287-94.

14 Holtzman MJ, Cunnigham JH, Sheller JR, Irsigler GB, Nadel JA, Boushey HA. Effect of ozone on bronchial reactivity in atopic and non-atopic subjects. Am Rev Respir Dis 1979;120:1059-67.

15 Nadel JA, Salem H, Tamplin B, Tokiwa Y. Mechanisms of bronchoconstriction during inhalation of sulphur dioxide. $J$ Appl Physiol 1965;20:164-7.

16 Orehek J, Massari JP, Gayrard P, Grimand C, Charpin C. Effect of short-term, low-level nitrogen dioxide exposure on bronchial sensitivity of asthmatic patients. J Clin Invest 1976;57:301-7.

17 Sellick $H$, Widdicombe JG. Stimulation of lung irritant receptors by cigarette smoke, carbon dust and histamine aerosol. $J$ Appl Physiol 1971;31:15-9.

18 Ruffin RE, Dolovich MB, Wolff RF, Newhouse MT. The effects of preferential deposition of histamine in the human airway. Am Rev Respir Dis 1978;117:485-92.

19 Orie NGM, Sluiter HJ, de Vries K, Tammeling GJ, Witkop J. The host factor in bronchitis. In: Orie NGM, Sluiter HJ, eds. Bronchitis: an international symposium, 27-29 April 1960: University of Groningen, the Netherlands. Springfield: Illinois, Charles C Thomas, 1961:43-59.

Accepted 12 February 1990

\section{Coincidence}

Coincidence is a potent mechanism for the propogation and maintenance of myths. Many a time the juxtaposition of an unconnected event and the appearance of symptoms of an illness convinces the person concerned (not to mention his doctor) that the two are causally related.

A young man was taken on to help excavate the site of an 18 th century infirmary cemetery. He had no previous experience of work of this type and needed constant reassurance that he would not "catch anything from the skeletons." All went well until he and a companion unearthed a lead coffin that was in poor condition and holed in a number of places. Both thought that they could smell an emanation from the coffin although later examination showed that the coffin contained nothing but bare bones. The young man was extremely anxious, and was sent home by the site director. The next day he presented with an eczematous rash on both cheeks, which he was sure was the result of exposure to some effluvium from the coffin. He refused to work on the site any further and the director advised him to see his own doctor and ask for referral to a dermatologist. In the meantime, the director sought some information herself but met with a conspicuous lack of success from the sources she contacted.

Eventually the report came back from the dermatologist that the young man had indeed acquired an allergic skin reaction, not to noxious vapours from the coffin, but from his girlfriend's new hair spray. $\mathrm{He}$, meanwhile, had found himself more congenial work, and the site director eventually managed to find a source of advice to whom she relayed this tale.

HA WALDRON Editor 